\title{
Risk factors of breast cancer in Mexican women*
}

\author{
A na Laura Calderón-Garcidueñas, M.C., M. en C., ${ }^{(1,2)}$ Franklin U riel Parás-Barrientos, M.C. ${ }^{(2)}$ \\ Lilia Cárdenas-Ibarra, M.C., (3) Juan Francisco González-Guerrero, M.C., ${ }^{(4)}$ \\ Enrique Villarreal-Ríos, M.C., M. en S.S., ${ }^{(5)}$ Tamara Staines-Boone, M.C., ${ }^{(1)}$ \\ Hugo A. Barrera-Saldaña, Biól., D r. en Cien. Bioméd.11
}

\section{Calderón-Garcidueñas AL, Parás-Barrientos FU, Cárdenas-Ibarra L, González-Guerrero JF, Villarreal-Ríos E, Staines-Boone T, Barrera-Saldaña HA. Risk factors of breast cancer in Mexican women. Salud Publica Mex 2000;42:26-33.}

\begin{abstract}
A bstract
Objective. To investigate the association between family history (FH) of neo plasia, gyneco-obstetric factors and breast cancer (BC) in a case-control study. In cases, to analyze those variables in relation with early onset of $B C$, the manner of detection (self-examination, prompted by pain, or casual), the size of tumor, and the elapsed time to seek medical attention. Material and methods D ata from 151 prevalent BC cases and 235 age-matched controls were analyzed by multiple logistic regression, to assess the influence of $B C$ risk factors. Results Ten per cent of patients and 1\% of controls had first-degree relatives (FDR) with BC. Family history of FDR with $B C(O R, 11.2 ; 95 \% \mathrm{Cl} 2.42-51.92)$ or with gastric or pancreatic cancer $(O R, 17.7 ; 95 \% \mathrm{Cl} 2.2$ 142.6) was associated with $B C$ risk. Breastfeeding at or under 25 years of age was protective against $B C(0 R, 0.40 ; 95 \% \mathrm{Cl}$ 0.24-0.66).The manner of tumor detection did not influence its size at the time of diagnosis. Conclusions O ur study confirms that $\mathrm{FH}$ of $\mathrm{BC}$ and/or of gastric or pancreatic carcino ma are risk factors for $\mathrm{BC}$, while lactation at 25 years of age or earlier is protective.
\end{abstract}

\author{
Calderón-Garcidueñas AL, Parás-Barrientos FU, \\ Cárdenas-Ibarra L, González-Guerrero JF, \\ Villarreal-Ríos E, Staines-Boone T, \\ Barrera-Saldaña HA. \\ Factores de riesgo de cáncer de mama \\ en mujeres mexicanas. \\ Salud Publica Mex 2000;42:26-33.
}

\section{Resumen}

Objetivo. Investigar la asociación entre la historia familiar de neo plasias, factores ginecobstétricos y cáncer mamario (CM) en un estudio de casos y controles. Además, en los casos, estudiar estas variables en relación con inicio temprano del cáncer, forma de detección (autoexamen, exploración individual por dolor o casual), tamaño del tumor. Material y métodos. Entre enero y marzo de 1997 se estudiaron 151 casos prevalentes de CM y 235 controles pareados por edad provenientes del Hospital de Especialidades del Centro Médico del Noreste, Instituto Mexicano del Seguro Social, 0 del Hospital Universitario de la U niversidad Autónoma de $\mathrm{N}$ uevo León, ambos localizados en Monterrey, México. Los factores de riesgo se analizaron con regresión logística múltiple. Resultados D iez por ciento de casos y $1 \%$ de controles tuvieron histo ria familiar de primer grado para CM; este antecedente (razón de momios-RM, 11.2; IC 95\%; 2.42-51.92) y el de carcinoma gástrico o pancreático (RM, 17.7; IC 95\%; 2.2-142.6) se asociaron con riesgo de CM. El amamantar a los 25 años o menos fue factor protector (RM, 0.40; IC 95\%; 0.24-0.66). La forma de detección del tumor no influyó en el tamaño del tumor al momento del diag-

\footnotetext{
Financial support was received from CONACYT (grant number 4318P-M9607).

(1) Unidad de Laboratorios de Ingeniería y Expresión G enéticas (ULIEG), D epartamento de Bioquímica, Facultad de Medicina, Universidad Autónoma de N uevo León (UAN L), México.

(2) Servicios de Patología y 0 ncología, Hospital de Especialidades del Centro Médico del N oreste, Instituto Mexicano del Seguro Social, Monterrey, N .L., México.

(3) Servicio de Endocrinología, Hospital Universitario Dr. José Eleuterio González, UAN L, México.

(4) Centro Universitario Contra el Cáncer, Hospital Universitario, UAN L, México.

(5) Unidad Regional de Investigación Epidemiológica y en Servicios de Salud, IMSS, Monterrey, N uevo León, México.
}

Recibed on:June $14,1999 \cdot$ Accepted on: N ovember 8,1999

Reprint requests to: Dr. Hugo A. Barrera-Saldaña. Departamento de Bioquímica, Facultad de Medicina, Universidad Autónoma de N uevo León. Avenida Madero y Dr. Eduardo A guirre Pequeño, colonia Mitras Centro C.P. 64460 Monterrey, N .L., México. E-mail: hbarrera@uanl.mx 
nóstico. Conclusiones. Se mostró que la historia familiar de CM y de carcinoma gástrico o pancreático son factores de riesgo para C M, mientras que la lactancia a los 25 años 0 antes, es protectora.

Palabras clave: neoplasmas de la mama; factores de riesgo; México

B reast cancer is a universal health problem. In the USA, one in every eight women will develop breast cancer $(\mathrm{BC})$ during her lifetime, to become one of the 180000 new cases reported annually. ${ }^{1}$ In Mexi$\mathrm{co}, \mathrm{BC}$ is the second most frequent malignant neoplasm in women. ${ }^{2}$ In 1993, 5739 new cases and 2718 deaths were registered in Mexico, with the latter increasing to 3106 in $1996 .^{2}$ Risk factors for BC are: early onset of menarche, late age at menopause, late first full-term pregnancy, and low parity; a protective factor is the removal of ovaries at an early age. Obesity increases the risk of $\mathrm{BC}$ in postmenopausal women. Having a first degree relative with BC confers an increased risk, especially if a mother and a sister had breast cancer at an early age. ${ }^{3}$ Population estimates of the percentage of BC cases associated with a family history of BC may lie between $6 \%$ and $19 \%$, depending on whether first degree or distant relatives are included. ${ }^{4}$ It is important to differentiate between first degree relatives and other relatives, and also to identify high risk families. The latter will have a high probability of harboring a mutation of a dominant BC susceptibility gene. Some authors have estimated that the frequency of dominant BC-related mutations is $0.33 \%$ and that it accounts for $5 \%$ of $\mathrm{BC}$ in the general population. ${ }^{5}$ Along with a woman's age, family history is the strongest risk factor for BC. 6

In Mexico, information is available on risk factors such as lactation ${ }^{7}$ and other reproductive determinants of $\mathrm{BC}_{,}^{8}$ while information is lacking on age at onset, detailed family history, association with other neoplasm, and bilateral manifestations. The aims of this work were: a) in a case-control study, to determine the frequency of familial $\mathrm{BC}$ and its relation with familial neoplastic history and gyneco-obstetric factors (GOF); b) to evaluate the distribution of variables such as familial neoplastic history and GOF in BC patients with and without an early onset of $\mathrm{BC}$, and c) to investigate breast self-examination behavior in patients, the manner of detecting the tumor, and its influence on the size of tumor at the time of diagnosis.

\section{Material and methods}

A case-control study was conducted after study subjects provided written informed consent. A sample of 152 (151 females, 1 male) BC cases and 235 healthy women was obtained. The male BC case was eliminated from statistical analysis, thus the final sample consisted of 151 women with BC.

Sample size was calculated according to frequencies reported in the literature, which state that approximately $10 \%$ of $\mathrm{BC}$ patients have first degree relatives with $\mathrm{BC}, 4,5$ and that the percentage of familial history of $\mathrm{BC}$ in women without $\mathrm{BC}$ is $2 \%$ or less. ${ }^{7,8}$ Using Epi Info $6,{ }^{9}$ for a case-control study with $95 \% \mathrm{CI}$ (alpha 0.05 , beta 0.20), the smallest sample was 111 patients and 222 controls, with a ratio of 1:2. Thus 151 cases and 235 controls were included.

Patients were recruited between January and March 1997, from a convenience sample of prevalent cases attending Hospital de Especialidades del Centro Médico del Noreste, Instituto Mexicano del Seguro Social, of the Mexican Government, or from the University Hospital of Universidad Autónoma de Nuevo León, both located in Monterrey, México. Hospital de Especialidades provides healthcare to formally employed subjects and their families. University Hospital is a hospital which charges the cost of medical care (total or partial) to patients, thus indigents are rarely attended at this hospital except for emergency cases.

Inclusion criteria for patients were: a history and confirmed histological diagnosis of $\mathrm{BC}$, to be a patient of an oncology department at participating hospitals, and consent to participate in an interview and to respond to a questionnaire.

Specific questions about age at onset of the disease and family history of $\mathrm{BC}$ and other neoplasms (ovary, cervix, stomach, pancreas, prostate, colon, lungs, blood tissue and lymph nodes, larynx, and brain) were directly asked to patients during the interview by two of the authors of this study. Only two patients, one from each hospital, refused to participate. 
Female controls in this work were participants in a study of bone mineral density conducted by one of the authors. Controls were recruited during the fall of 1996 and the summer of 1997. Participation of controls was $69.8 \%$. Information about control candidates who refused to participate is limited to age and telephone number.

Eligibility criteria for controls were: to be 25 years of age or older, currently healthy, to agree to the interview, and to respond to a questionnaire. Exclusion criteria were: pregnancy and lactation, chemotherapy or steroid therapy, renal impairment, thyroideal or parathyroideal disease, and being bed-ridden because of illness for at least 2 weeks, during the month prior to recruitment. The sampling of control women began with the list of home addresses in Monterrey. The multistep selection utilized the 1996 white-page phonebook, a grid of 100 divisions, two list of telephone numbers by resident name, address and zip code. Each grid cell contained from 0 to 4 addresses; one address was randomly chosen from cells with more than one address. Home dwellers were contacted by phone to identify women in the household. Selection through the Kish inventory code was used in homes with more than one eligible woman. Selected women attended the out-patient clinic of the University Hospital for an interview and complete clinical history with physical exam and laboratory tests (blood and urine samples). Women's interviews were performed by five registered nurses previously trained, who inquired about first-degree neoplastic family history (except for children).

Statistical methods were calculated using the SPSS/PC package. Characteristics of patients and controls regarding onset of $\mathrm{BC}$ were compared. Continuous variables between both groups were examined with the $t$ - test and Levene's test for equality of variances. $\chi^{2}$ test was used with nominal variables to assess the number of subjects having higher $v$ s. equal or lower than median for the putative risk factor been investigated. Variables included were: age, menarche, years of exposure to endogenous estrogens (obtained by substracting age at menarche from age at menopause, or age at the interview minus months of pregnancies and lactation), affirmative history of use of hormonal contraceptives (HCC), total years of exposure to hormonal contraceptives, number of full-term pregnancies, miscarriages (1 or more), months of lactation $(>$ or $\leq 9)$ and body mass index $\left(\mathrm{kg} / \mathrm{m}^{2}\right)$.

Crude OR with $95 \% \mathrm{CI}$ were obtained to assess the relationship of BC with investigated factors. These variables were also tested in multivariate fashion by logistic regression (forward conditional selection method), setting $p$-in at 0.05 and $p$-out at 0.10 . Crude and adjusted odds ratios for women with BC compared to controls were calculated for number of women with first-degree relatives with breast, gastric and/or pancreatic cancer, and cervical cancer, history of one or more miscarriages, full-term pregnancies (with three categories, none, $1-4,5+)$, age at first delivery $(>25$ years, $<25$ years), age at first lactation ( $>$ or $<25$ years), lactation time per child ( $<$ or $>6$ months) and history of breastfeeding (yes /no).

Additionally, crude and adjusted odds ratios were estimated for: patients with early onset (35 years old or younger) BC compared to patients without it; first and second (separately) degree relatives with BC; first and second degree relatives with gastric and/or pancreatic and ovarian carcinomas; bilateral carcinoma; menarche ( $<$ or $>14$ years); miscarriage (any or none): childbirth (yes/no); age at delivery of first child ( $>$ or $<25$ years); age at first lactation ( $>$ or $<25$ years); lactation per child (obtained by dividing the total number of lactation months by number of children) $(<$ or $>6$ months); and history of breastfeeding (yes/no).

Finally, the manner in which cases detected the tumor was investigated. Detection was considered casual when women detected the tumor accidentally (as when washing the breast region while showering), selfexamination was considered when women intentionally examined clinically asymptomatic breasts; and prompted by pain if a breast was examined by the patient or a medical worker (physician or nurse) due to pain. In these three different groups, time between detection of tumor and first medical care was investigated; periods compared were less or more than a week. Size of tumor in the three groups was also analyzed. Continuous variable comparison in the three groups was assessed with one-way ANOVA with Levene's test for variances; nominal variables with more than $2 \times 2$ categories were tested with $\chi^{2}$.

\section{Results}

Table 1 shows characteristics of cases and controls. As can be seen, there were no differences between the two groups in relation to age, menarche, time to exposure to endogenous estrogens, total years of exposure to hormonal contraceptives, number of full-term pregnancies, miscarriages, total months of lactation and being overweight.

Both groups were similar in the number of years of formal education, being the median $7 \pm 4$ for women younger than 50 years of age $(p=0.19)$. Likewise, both belonged to middle socioeconomic class. All controls and $76.8 \%$ of patients had telephone service. Three fourths of patients attended the Hospital de Especiali- 
Table I

Characteristics of breast cancer patients and controls. Monterrey, MeXico, 1997

\begin{tabular}{|c|c|c|c|c|}
\hline & $\begin{array}{l}\text { Patients } \\
(n=151)\end{array}$ & $\begin{array}{l}\text { Controls } \\
(n=235)\end{array}$ & Test & $\begin{array}{c}\text { Significance } \\
p\end{array}$ \\
\hline A ge mean $\pm S D$ & $49.9 \pm 12.6$ & $47.3 \pm 13.0$ & t-test $=1.92$ & $=0.055$ \\
\hline range & $24-80$ & $25-87$ & & \\
\hline \multicolumn{5}{|l|}{ Menarche (median 13) } \\
\hline$>13$ & 53 & 66 & $\chi^{2}=2.12$ & $=0.15$ \\
\hline$\leq 13$ & 98 & 169 & & \\
\hline Estrogen exposure* (years) & $28.8 \pm 7.3$ & $28.6 \pm 7.2$ & t-test $=0.31$ & $=0.75$ \\
\hline Use of HCC & 34 & 82 & $\chi^{2}=6.69$ & $<0.01$ \\
\hline Exposure to HCC (years) & $4.3 \pm 3.4$ & $3.9 \pm 3.5$ & $M-W=1224.5$ & $=0.30$ \\
\hline \multicolumn{5}{|l|}{ Full term pregnancies } \\
\hline$>3$ & 67 & 93 & $\chi^{2}=0.87$ & $=0.35$ \\
\hline$\leq 3$ & 84 & 142 & & \\
\hline
\end{tabular}

Miscarriages

\begin{tabular}{lllll}
$>1$ & 32 & 26 & $\chi^{2}=3.3$ & $=0.07$ \\
\hline$=1$ & 27 & 42 &
\end{tabular}

Lactation (months)

\begin{tabular}{lcccc}
$>9$ & 79 & 112 & $\chi^{2}=0.798$ & $=0.37$ \\
\hline$\leq 9$ & 72 & 123 & & \\
Body Mass Index $\left(\mathrm{Kg} / \mathrm{m}^{2}\right)$ & $28.4 \pm 5.1$ & $28.5 \pm 5.2$ & t-test $=0.15$ & $=0.88$
\end{tabular}

* It is calculated from menopause minus menarche, minus months of lactation and pregnancies. Twenty four patients (15.9\%) and $28(11.9 \%)$ controls who had histerectomy were included (comparison did not change significantly). HCC =hormonal contraceptives, number of users. M-W $=$ Mann-W hitney U test. No Levene's tests for equality of variances were significant

dades, the remaining were patients at the University Hospital. All patients were residents of the Northeast region of Mexico: 83 (54.9\%) patients lived in the metropolitan area of Monterrey, $21(13.9 \%)$ in other cities of Nuevo Leon State, 33 (21.9\%) from Coahuila and $14(9.3 \%)$ from the States of Tamaulipas and San Luis Potosi. Although controls were exclusively residents of Monterrey, they shared with patients similar characteristics, including climate, dietary habits, ethnic, cultural, and geographic factors. ${ }^{10}$

Table 2 shows the crude and adjusted OR for neoplastic familial history and GOF between BC patients and controls. Family history of BC was found in $20 \%$ of patients. When all first degree relatives were included, $10 \%$ of patients had first degree relatives with BC; when only the mother and siblings were considered, $8.6 \%$ was found in patients and $1 \%$ in controls. Twelve of the 151 patients had first degree relatives (offspring not included) with gastric or pancreatic carcinoma. Gastric carcinoma was the second most common malignant neoplasm in patients' relatives, with ten patients having first degree relatives (including offspring) with this neoplasm. Some patients had more than one relative affected with these carcinomas. As shown in Table 2, a history of first degree relatives with BC and gastric or pancreatic carcinomas was significantly more frequent in patients than in controls while no difference was found for carcinoma of the cervix. To have one or more miscarriages, the number of full term pregnancies, age at first delivery, and history of breastfeeding, showed no difference between patients and controls; however, breastfeeding at 25 years of age or younger $(52.9 \%$ vs. $67.6 \%)$ was significantly more frequent in controls in spite of the apparently longer 
Table II

FAMILY HISTORY OF CARCINOMA AND GYNECO-OBSTETRIC FACTORS BETWEEN BREAST CANCER PATIENTS AND CONTROLS. MonterRey, MeXico, 1997

\begin{tabular}{lrrrrrrrr} 
& $\begin{array}{c}\text { Patients } \\
n=151\end{array}$ & $\begin{array}{c}\text { Controls } \\
n=235\end{array}$ & $\begin{array}{c}\text { Crude } \\
\text { OR }\end{array}$ & $\begin{array}{c}95 \% \mathrm{Cl} \\
\text { Low-High }\end{array}$ & $\begin{array}{c}\mathrm{M} \text { ultivariate } \\
\text { OR }\end{array}$ & $\begin{array}{c}95 \% \mathrm{Cl} \\
\text { Low-High }\end{array}$ & $\begin{array}{c}\mathrm{P} \\
\text { First degree relative with BC* } \\
\quad \text { Yes }\end{array}$ \\
\hline N 0 & 13 & 2 & 11.1 & $2.5-49.9$ & $<0.001$ & 11.2 & $2.42-51.92$ & $<0.01$ \\
\hline
\end{tabular}

First degree relative with pancreatic or gastric CA

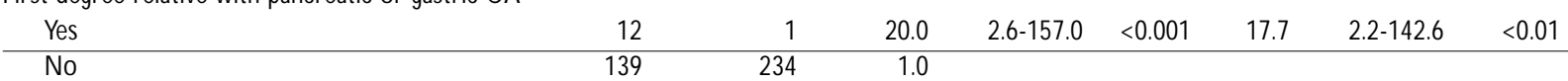

First degree relative with cervix CA

\begin{tabular}{|c|c|c|c|c|c|c|c|c|}
\hline Yes & 3 & 5 & 0.93 & $0.22-3.96$ & $=0.92$ & 1.92 & $0.34-10.75$ & $=0.45$ \\
\hline No & 148 & 230 & 1 & & & & & \\
\hline \multicolumn{9}{|l|}{ Miscarriage } \\
\hline 1 or $>$ & 59 & 68 & 1.57 & $1.02-2.43$ & $<0.04$ & 1.37 & $0.85-2.2$ & $=0.19$ \\
\hline None & 92 & 167 & 1.0 & & & & & \\
\hline \multicolumn{9}{|c|}{ Full term pregnancies } \\
\hline None & 22 & 29 & 0.94 & $0.47-1.85$ & $=0.85$ & 1.03 & $0.33-3.2$ & $=0.95$ \\
\hline $1-4$ & 87 & 147 & 1.2 & $0.75-1.94$ & $=0.44$ & 1.45 & $0.40-5.25$ & $=0.57$ \\
\hline 5 or $>$ & 42 & 59 & 1.0 & & & & & \\
\hline
\end{tabular}

Age at $1^{\text {st }}$ child

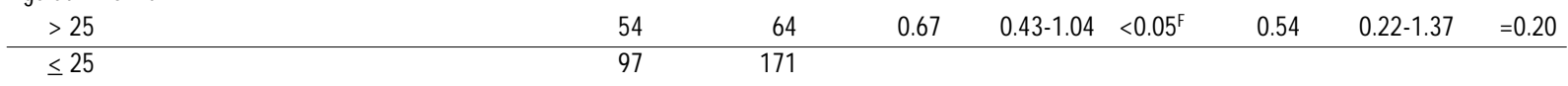

$1^{\text {st }}$ lactation at

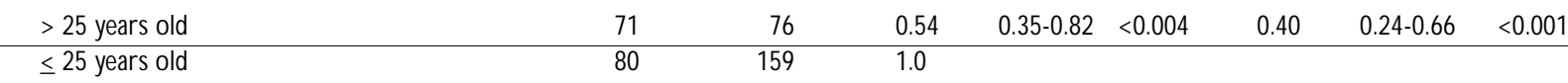

Lactation per child

\begin{tabular}{lrrrrrrrr}
$<6$ months & 89 & 154 & 1.3 & $0.86-2.01$ & $=0.19$ & 0.47 & $0.28-0.77$ & $<0.01$ \\
\hline$>6$ months & 62 & 81 & 1.0 & & & & &
\end{tabular}

Ever breastfeeding

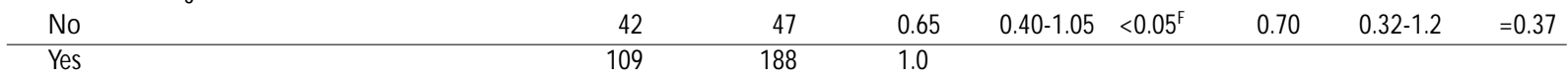

\footnotetext{
* Because descent relatives were not investigated in controls, two patients with only breast cancer children were excluded. F= Fisher's exact test. Multivariate $=$ Logistic regression (forward conditional), last model $\chi^{2} 48.1$, df $4, p<0.0001$
}

breastfeeding time per child in patients than in controls $(41 \%$ vs. $34.4 \%)$.

Table 3 shows the crude and adjusted OR for neoplastic family history and GOF between BC patients with and without early onset of BC.

In our sample of Northeastern Mexican women, $25(16.5 \%)$ had an early onset of the disease, including one the two patients with bilateral carcinoma. Only two out of 25 early onset cancer patients had firstdegree relatives with a breast neoplasm.
Of the variables analyzed in Table 3, having a relative with ovarian carcinoma and a bilateral cancer showed a tendency to be more frequent in patients than in controls. Menarche at 14 years of age or younger increased the risk of early onset of tumor; having the first child at or younger than 25 years and a history of breastfeeding had a protective effect.

Table 4 shows that the most frequent manner of tumor detection was casual. Ninety per cent of casual tumor detection occurred while showering. Medical 
Table III

FAMILY HISTORY OF CARCINOMA AND GYNECO-OBSTETRIC FACTORS AMONG PATIENTS With AND Without EARly ONSET Of BReAst CANCER. MonterReY, MEXICO, 1997

$\begin{array}{cccccccc}\text { Early Onset } & \text { Late Onset } & \text { Crude } & 95 \% \mathrm{Cl} & p & \text { Multivariate } & 95 \% \mathrm{Cl} & p \\ n=25 & n=126 & \text { OR } & \text { Low-High } & & \text { OR } & \text { Low-High } & \end{array}$

First degree relative with $\mathrm{BC}$

\begin{tabular}{lrrllllll} 
Yes & 2 & 13 & 0.76 & $0.16-3.58$ & $=0.53^{\mathrm{F}}$ & 1.48 & $0.23-9.37$ & $=0.60$ \\
\hline No & 23 & 113 & 1.0 & & & & &
\end{tabular}

Second degree relative with $\mathrm{BC}$

\begin{tabular}{lrrllllll} 
Yes & 1 & 15 & 0.31 & $0.04-2.45$ & $=0.21^{\mathrm{F}}$ & 3.77 & $0.40-35.53$ & $=0.24$ \\
\hline No & 24 & 111 & 1.0 & & & & &
\end{tabular}

Relative with ovarian CA

\begin{tabular}{lrrrrrrrr} 
Yes & 4 & 3 & 7.81 & $1.63-37.42$ & $<0.01^{\mathrm{F}}$ & 5.94 & $0.96-32.17$ & $=0.07$ \\
\hline No & 21 & 123 & 1 & & & & &
\end{tabular}

Relative with pancreatic/gastric CA

\begin{tabular}{lrrllllll} 
Yes & 3 & 13 & 1.19 & $0.31-4.51$ & $=0.56^{\mathrm{F}}$ & 1.38 & $0.35-5.38$ & $=0.64$ \\
\hline No & 22 & 113 & 1.0 & & & &
\end{tabular}

Bilateral breast CA

\begin{tabular}{lrrrrrrrr} 
Yes & 1 & 1 & 5.21 & $0.32-86.17$ & $=0.30^{\mathrm{F}}$ & 13.63 & $0.64-174$ & $=0.06$ \\
\hline N $~$ & 24 & 125 & 1.0 & & & & &
\end{tabular}

Menarche

\begin{tabular}{lrlllllll}
$<14$ years old & 22 & 76 & 0.21 & $0.06-0.73$ & $<0.009$ & 0.17 & $0.04-0.66$ & $<0.01$ \\
\hline$\geq 14$ years old & 3 & 50 & 1.0 & & & & &
\end{tabular}

Miscarriage

\begin{tabular}{lrrrrrrrr} 
Any & 6 & 53 & 0.43 & $0.16-1.16$ & $=0.06^{\mathrm{F}}$ & 3.40 & $0.86-13.44$ & $=0.08$ \\
\hline None & 19 & 73 & 1.0 & & & & & \\
Children & & & & & & & & \\
No & 5 & 17 & 0.62 & $0.20-1.88$ & 0.28 & 0.68 & $0.09-5.3$ & $=0.40$ \\
\hline Yes & 20 & 109 & 1.0 & &
\end{tabular}

1st child

\begin{tabular}{lrrrrrrrr}
$>25$ years old & 7 & 47 & 1.0 & $0.59-3.93$ & $=0.37$ & 7.49 & $1.71-32.85$ & $<0.008$ \\
\hline$\leq 25$ years old & 18 & 79 & 1.53 & & & & &
\end{tabular}

1st lactation

\begin{tabular}{lllllllll}
$>25$ years old & 14 & 57 & 0.65 & $0.27-1.54$ & $=0.37$ & 0.78 & $0.071-8.6$ & $=0.75$ \\
\hline$\leq 25$ years old & 11 & 69 & 1.0 & & & & &
\end{tabular}

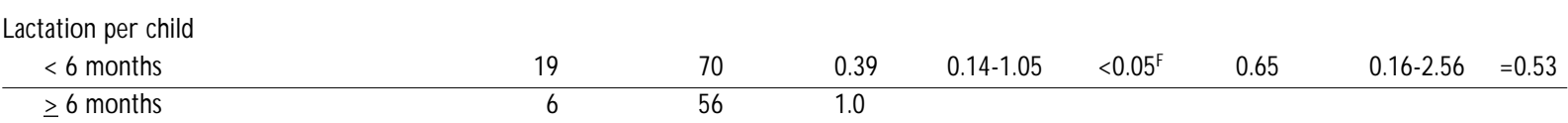

Breastfeeding

\begin{tabular}{lllllllll} 
No & 13 & 29 & 0.28 & $0.11-0.67$ & $<0.005$ & 0.095 & $0.02-0.39$ & $<0.001$ \\
\hline Yes & 12 & 97 & 1.0 & & & & &
\end{tabular}

$\mathrm{F}=$ Fisher's exact test (one tiled). Multivariate: Logistic regression (Forward conditional: $p$-in 0.05 , $p$-out 0.1). Last model $\chi^{2} 28.8$, df $4, p<0.0001$ Early onset $\leq 35$ years, $B C=$ breast cancer, $C A=$ carcinoma 


\section{Table IV \\ Health behavior and size of the tumor IN THE 151 BREAST CANCER WOMEN PATIENTS. Monterrey, Mexico, 1997}

\begin{tabular}{|c|c|c|c|}
\hline Detected by & $n(\%)$ & M edical A $<1$ sem $* \%$ & $\begin{array}{l}\text { Tumor size }(\mathrm{cm})^{\ddagger} \\
\text { Mean } \pm \mathrm{SD}\end{array}$ \\
\hline elf exam & $44(29.1)$ & 66 & $5.3 \pm 3.3$ \\
\hline ain & $19(12.6)$ & 90 & $6.4 \pm 3$ \\
\hline asual & $88(58.3)$ & 32.5 & $5.8 \pm 4$ \\
\hline \multicolumn{4}{|c|}{$\begin{array}{l}\text { * \% of patients who looked for medical care a week or less than a week } \\
\text { after the tumor was discovered. } \chi^{2}=8.6 \text {, with } 2 \text { degrees of freedom, } \\
p<0.05 \text {. } \\
\text { one way AN O VA was not significant. } F=0.59, p=0.56 \text {; Levene test } 0.52 \text {, } \\
p=0.60\end{array}$} \\
\hline
\end{tabular}

care seeking during the first week after detecting the tumor was significantly higher among women who practiced self-exam, than among women who did not practice it. The majority of women with pain sought medical care. The relative advantage of women who practiced self-exam did not result in the detection of smaller tumors, as evidenced by the similar size of tumors in the three groups. In our patients, there were only cases of infiltrating carcinomas and just in 7 cases the tumor was $1 \mathrm{~cm}$ in diameter or less.

\section{Discussion}

This study was carried out to determine the frequency of family history of breast cancer and to evaluate the relationship of breast cancer with familial neoplastic history and gyneco-obstetric factors (GOF). In addition, a case-only analysis was conducted, to assess the relationship of the above mentioned factors with early onset of $\mathrm{BC}$, and the manner of tumor detection and other variables.

Before discussing the findings, some methodological issues should be considered. Cases were a convenience sample and this has limitations and potential bias; however, cases were comparable with other patients seen at the two hospitals throughout the same period of time, and with the totality of patients who attended the hospitals during the same year of recruitment. They had similar characteristics regarding age, sex, and histological type and size of tumor. Although the sample size is limited, it has enough power to differentiate between patients and controls when family history is tested. Ideally, control women should share a similar distribution in relation to place of residence; in this study controls included only residents of Monterrey. However, we do not find strong evidence to suppose that they were substantially different from patients. ${ }^{10}$ Furthermore, the same findings were observed when only patients from Monterrey were compared to controls. Patients from the two hospitals had similar characteristics. Data collection was performed by trained interviewers and we consider that recall bias in patients and controls is unlikely to have affected our study results.

In this study, the main risk factors for $\mathrm{BC}$ in women from the Northeast region of Mexico were: having first degree relatives with $\mathrm{BC}$, and gastric or pancreatic cancer.

It is known that family history of $B C$ increases the risk of having this disease and the risk is modified if the mother, a sister, or both are affected, and in general if first or second degree relatives have BC..1 $\mathrm{Ad}$ justed OR 95\% CI for family history is reported between 2.3 and 4.5 depending of the type of relative involved ${ }^{11}$ and it increases if many relatives are affected. In this study an adjusted OR of 11.2 was found, supporting the importance of this factor in our population. However, this OR is certainly higher than any other reported in the literature in relation with family history of breast cancer. ${ }^{11}$ It may be explained partially because of the low frequency of first-degree relatives with BC reported by controls ( 2 of 235 controls, $0.85 \%$ ). Such a low number of family history in controls may result in an inflated estimate of increased risk due to family history. We do not have an explanation for such a low rate; controls and patients were directly and thoroughly interrogated about family history of breast cancer in first degree relatives; difference in ages between controls and patients (t-test 1.92, $p=0.055$ ) neither explains a lower probability of controls to have relatives with breast cancer. This increased risk should be investigated in future studies in our population. History of first degree relatives with gastric and pancreatic carcinoma was also significantly more frequent in patients than in controls. Carcinoma of the cervix is the most frequent neoplasm in women in Mexico, ${ }^{2}$ thus it is a good index of comparison. However there was no difference in the frequency of this neoplasm between the groups. This finding supports the fact that both groups are comparable. Recently, it has been discovered that clustering of first degree cases of breast, pancreas and stomach carcinomas in a family has been associated with mutations in the $\mathrm{BC}$ susceptibility gene BRCA2. ${ }^{12}$ This finding should be investigated in further studies in our population.

It is known that age at first delivery is a risk modulator of breast cancer. The first pregnancy before 25 years of age induces the terminal differentiation of breast cells and has a protective effect against cancer. ${ }^{13}$ 
Recently, molecular studies have suggested that the normal protein of the BRCA1 gene may mediate the protective effect of pregnancy and lactation by inhibiting proliferation of breast epithelial cells. ${ }^{14}$ In our study, while apparently there was no difference in the number of children between patients and controls, when the mother was 25 years old or younger at the time of breastfeeding the first baby, a significant difference between the groups was evident, confirming its protective effect, consistent with previous reports in Mexican studies. ${ }^{7}$ The use of hormonal contraceptives was more frequent in controls than in patients; however, there was no difference in years of exposure to hormonal contraceptives between the groups.

Interestingly, the analysis of neoplastic familial history and GOF in patients to determine its association with early onset of $\mathrm{BC}$ showed that menarche at younger than 14 years of age, increased the risk of early onset $\mathrm{BC}$ and that the history of a relative with ovarian carcinoma and to have bilateral tumors had a tendency to be more frequent in early onset BC patients; these variables deserve further investigation. Although early onset $B C$ patients more frequently had their first child at 25 years of age or younger, there were no differences in the age at the first lactation period in both groups. However, history of breastfeeding seemed to be protective against early onset $\mathrm{BC}$. Other variables tested that have been associated with increased risk of $\mathrm{BC}$ or with protection against it, did not seem to influence early onset BC. Some authors have reported that approximately $12 \%$ of women with early onset BC have BRCA1 gene mutations, and it is known that the association of breast cancer and ovarian cancer in a family strongly support the presence of mutations in this gene. ${ }^{15}$

Finally, in spite of promotion campaigns of the Mexican National Health System to induce the habit of breast self-examination in the population, we found that only a third of women regularly practice it. Another surprising finding was that there was no significant difference in the size of the tumors discovered by patients who practice and those who do not practice breast self-exam; in fact, there were only cases of infiltrating carcinomas in our patients. The only significant difference was that more patients with regular selfexam practice consulted a physician during the first week after discovering the tumor.

In conclusion, this work provides information, especially related with family history of breast and other carcinomas. It supports the findings that women's age, along with family history, constitute the strongest risk factors for BC. Moreover, it shows that family history of gastric and pancreatic cancer is also a risk factor for BC in this study population, and emphasizes the protective influence of lactation against breast cancer.

\section{Acknowledgement}

We express our gratitude to patients and controls for their cooperation; Prof. R. M. Chandler-Burns and Dr. Mike Badzioch, for critical reading of our manuscript.

\section{References}

1. American Cancer Society. C ancer Facts \& Figures. Atlanta, 1995:10-11. 2. Registro histopatológico de neoplasias en México. Departamento General de Estadística. Secretaría de Salubridad y Asistencia. México, 1993 y 1996.

3. Kelsey JL, Bernstein L. Epidemiology and prevention of breast cancer. Annu Rev Public Health 1996;17: 47- 67.

4. Hoskins K, Stopfer J, Calzone K, Merajver S, Rebbeck T, Garber J, et al. Assessment and counseling for women with a family history of breast cancer:A guide for clinicians. JAMA 1995;273:577- 585.

5. Claus EB, Risch N, Thompson W D. Genetic analysis of breast cancer in the cancer and steroid hormone Study. Am J Hum Genet 1991;48: 232-242.

6. Brody L, Bowels-Biesecker B. Breast Cancer:The high-risk mutations. Hosp Prac 1997;0 ct:59-80.

7. Romieu I, Hernández-Avila M, Lazcano E, López L, Romero-Jaime R. Breast cancer and lactation history in Mexican women. Am J Epidemiol 1996;143(6):543-552.

8. López Carrillo L, Bravo-Alvarado J, Poblano-Verástegui 0, 0 rtega-Altamirano D. Reproductive determinants of breast cancer in Mexican women.Ann N Y Acad Sci 1997;837:537-550.

9. Center for Disease Control \& Prevention Epi Info 6. Ginebra:World Health O rganization, 1994.

10.González-Q uiroga G, Ramírez del Río JL,C erda-Flores RM, G arza C hapa $R$. Frequency and origin of G-6-PD deficiency among icteric newborns in the metropolitan area of Monterrey, N vo. León, México. G ene G eography 1994;8:157-164.

11.Viladiu P, Izquierdo A, Sanjosé S, Bosch F.A breast cancer case-control study in Girona Spain. Endocrine, familial and lifestyle factors. Eur J Cancer Prev 1996;5:329-335.

12. Schubert E, Lee M, Mefford H,A rgonza R, Morrow J, Hull J, et al. BRCA2 in American families with four or more cases of breast or ovarian cancer: Recurrent and novel mutations, variable expression, penetrance, and the possibility of families whose cancer is not attributable to BRCA1 or BRCA2. Am J Hum Genet 1997;60:1031-1040.

13. Lambe M, H sieh CC, Chan HW, Ekbom A, Trichopoulos D, Adami HO. Parity, age at first and last birth, and risk of breast cancer:A populationbased study in Sweden. Breast Cancer Res Treat 1996;38(3):305-311.

14. Jensen $R$, Thompson M, Jetton T, Szabo $C$, van der Meer R, Helou $B$ et al. BRCA 1 is secreted and exhibits properties of a granin. $N$ ature $G$ enet 1996;12(3):303-308.

15. Krainer M, Silva-Arrieta S, FitzG erald MG, Shimada A, Ishioka C, et al. Differential contributions of BRCA1 and BRCA2 to early-onset breast cancer. N Engl J Med 1997;336(20):1416-1421. 